\title{
Transfer of Arsenic from Groundwater and Paddy Soil to Rice (Oryza sativa L.) Grain: A Micro Level Study in Chandina, Comilla
}

\author{
Md. Habibur Rahman ${ }^{1}$, Md. Mohashin Farazi ${ }^{1}$, Kohinoor Begum ${ }^{2}$ and Md. Serazul Islam ${ }^{3}$ \\ ${ }^{1}$ Central Laboratory, Soil Resource Development Institute, Krishi Khamar Sarak, Dhaka-1215; \\ ${ }^{2}$ Dhamrai Government College, Dhaka; ${ }^{3}$ Chemist Agro-biotech Limited, Bangladesh \\ *Corresponding author and Email: habibso.bd@gmail.com
}

Received: 10 January 2014

Accepted: 13 December 2014

\begin{abstract}
Rice (Oryza sativa L.) is one of the major food crops in many countries. As the cultivation of rice requires huge volume of water, long term use of Arsenic contaminated groundwater for irrigation may result in the increase of arsenic concentration in the agricultural soil and eventually accumulation in rice grains. A micro level study was conducted to investigate the transfer of arsenic from irrigation water and soil to rice plants in the arsenic affected 8 unions of Chandina upazilla, Comilla district. The level of arsenic in irrigation water $\left(0.12 \pm 0.08\right.$ and $\left.0.67 \pm 0.07 \mathrm{mg} \mathrm{l}^{-1}\right)$ was much above the WHO permissible limit of $0.01 \mathrm{mg} \mathrm{l}^{-1}$ for drinking water and FAO permissible limit of $0.10 \mathrm{mg} \mathrm{l}^{-1}$ for irrigation water. The total soil arsenic concentrations ranged from $3.21 \pm 0.80$ to $8.74 \pm 2.83 \mathrm{mg} \mathrm{kg}^{-1} \mathrm{dry}^{-1}$ weight of soil, which was below the maximum acceptable limit for agricultural soil of $20.0 \mathrm{mg} \mathrm{kg}^{-1}$ as recommended by the European Community. The accumulation of arsenic in the grain ranged from $0.12 \pm 0.04$ to $0.58 \pm 0.06 \mathrm{mg} \mathrm{kg}^{-1}$ in Boro and $0.16 \pm 0.04$ to $1.06 \pm 0.20 \mathrm{mg} \mathrm{kg}^{-1}$ in $\mathrm{T}$. Aman. Except grain sample (T. Aman) of one union, the grains in both Boro and T. Aman of all unions did not exceed 1.0 $\mathrm{mg} \mathrm{kg}^{-1}$ dry weight of arsenic (the permissible limit of arsenic in rice according to WHO recommendation). Thus, till now rice has remained harmless for consumption in the study area. The results clearly showed that the arsenic content in the grains of Boro rice is correlated to the intensity of arsenic contamination of irrigation water and soil.
\end{abstract}

Keywords: Arsenic, bioaccumulation, groundwater, rice, irrigation water

\section{Introduction}

Groundwater arsenic contamination in the Bengal Delta Plain has been termed as the largest mass poisoning in human history (Smith et al., 2000). It is widely distributed in nature and is associated with igneous and sedimentary rocks, particularly with sulphide ore. Natural phenomena such as weathering, biological activity and volcanic activity, are responsible for the emission of arsenic into the atmosphere where from it is distributed on the earth's surface by rain and dry fall out. Besides these, anthropogenic activities such as pesticide and herbicide applications, mining and irrigation with contaminated groundwater have significantly enhanced arsenic levels in agricultural soil in many parts of the world (Marin et al., 1992).

Bangladesh is currently facing a challenge of high arsenic concentration in shallow aquifers (Nickson et al., 1998). A large number of hand and shallow tube wells (STW) in some of the 
localities of 59 districts out of 64 have been identified to have arsenic (As) concentration above the Bangladesh standard of $0.05 \mathrm{mg} \mathrm{kg}^{-1}$ (Alam et al., 2002). To meet up the growing demand for food, the farmers had to cultivate high yielding varieties of Boro rice, which requires a large volume of irrigation water. Irrigation with arsenic contaminated groundwater to rice increases its concentration in soil (Jahiruddin et al., 2000; Meharg et al., 2003 and Ali et al., 2003), and eventually, arsenic enters into food chains through crop uptake and poses long term risk to human health (Duxbury et al., 2003; Islam et al., 2004 a).

Most of the reports focus mainly on the uptake of arsenic in the rice plant irrigated with arsenic contaminated water and soil through green house pot experiments (Abedin et al., 2002; Rahman et al., 2008; Delowar et al., 2005). However, the field level investigation is quite inadequate on this aspect. Thus, the present study was to undertaken determine the concentration of arsenic in irrigation water, paddy field soil cultivated with the arsenic contaminated irrigation water and soil in the Chandina upazilla of Comilla district. This study would help to understand the transfer of arsenic from irrigation water and paddy soil to the rice plant.

\section{Materials and Methods}

\subsection{Study area}

The present study conducted in the area where the level of Arsenic in ground water exceeded WHO permissible limit $\left(0.01 \mathrm{mg} \mathrm{l}^{-1}\right)$ for drinking water (WHO, 1992) and FAO permissible limit for irrigation water $\left(0.10 \mathrm{mg} \mathrm{l}^{-1}\right)$ ( FAO, 1985). Thirty eight samples were collected from the eight unions of this upazilla namely Mahichal, Gollai, Dollai Nawabpur, Madhaia Joag, Borokorai, Maijkhar and Barera.

\subsection{Sample collection}

Irrigation water samples were collected from the shallow and deep shallow tube well pumps which were used for irrigation in the study area. Prior to sample collection, the pumps were kept running for about10-15 minutes in order to get a uniform rate of discharging water. Then the water samples were collected in the plastic bottles and preserved with $6 \mathrm{~N} \mathrm{HCl}$. Soil and rice samples were collected from the fields irrigated with the arsenic contaminated water and transferred to airtight polythene bags. Soil samples were also collected from $10-15 \mathrm{~cm}$ depth in using GPS reading. Rice grain samples were collected in the same position from where soil samples were collected during harvesting time both in Boro and Aman seasons.

\subsection{Sample treatment}

The irrigation water samples were filtered using Whatman Filter Paper No.42 and were kept inplastic bottle for analysis. The soil samples after collection were immediately dried. The driedsoil samples were then grinded and passed through $2.0 \mathrm{~mm}$ pore sized sieve to get homogenized representative powder sample. Finally the samples were stored in airtight polyethylene bags at room temperature. The rice grain samples were dried in the Hot Air Oven at $60^{\circ} \mathrm{C}$ for 72 hours and were stored in airtight polyethylene bags at room temperature. Proper care was taken at each step to minimize any sort of contamination.

\subsection{Sample digestion and analysis}

Soil samples and grain portions of the rice samples were digested separately following heating block digestion procedure (Rahman et al., 2007). About $1.0 \mathrm{gm}$ soil sample and $2.0 \mathrm{gm}$ rice grain sample were taken into clean dry digestion tubes and $10 \mathrm{ml}$ of concentrated $\mathrm{HNO}_{3}$ was added to it. The mixture was allowed to stand overnight under fume hood. In the following day, thedigestion tubes were placed on heating block and heated at $60^{\circ} \mathrm{C}$ for 2 hours. The tubes were then allowed to cool down at room temperature. About $5 \mathrm{ml}$ of concentrated $\mathrm{HClO}_{4}$ was added to the samples. Then the tubes were heated at $160^{\circ} \mathrm{C}$ for about $4-5$ hours. The heating was stopped when the dense white fume of $\mathrm{HClO}_{4}$ was emitted. The content was then cooled, diluted to $50 \mathrm{ml}$ with de-ionized water filtered through Whatman No. 42 filter papers 
and finally stored in plastic bottles. Prior to sample digestion all glass goods were washed with $2 \% \mathrm{HNO}_{3}$ followed by rinsing with deionized water and drying.

Total arsenic of the digested soil, rice grain and irrigation water samples were analyzed by flowinjection hydride generation ICP-OES using external calibration through arsenate as standard (Welsch et al., 1990). The optimum $\mathrm{HCl}$ concentration was $6 \mathrm{~N}$ and $3 \% \mathrm{NaBH}_{4}$ produced the maximum sensitivity.

\subsection{Statistical data analysis}

Pearson's correlation coefficient (r) was carried out to find out the correlation among arsenic concentrations in irrigation water, irrigated field soil and rice grains (Boro and T. Aman) by SPSS software.

\section{Results and Discussion}

In the present study, sample of irrigation water, agricultural field soil and rice grain were collected from the arsenic affected eight unions of Chandina upazilla of Comilla district and analyzed. The selected physicochemical properties of the soil and the concentrations of arsenic in irrigation water, soil and in the grain of the rice plant cultivated in the Chandina are presented in Table1 and Table 2, respectively.

The results show that the average arsenic concentration in the irrigation water lies between $0.12 \pm 0.08$ and $0.67 \pm 0.07 \mathrm{mg} \mathrm{l}^{-1}$ and that in the agricultural field soil lies between $3.21 \pm 0.80$ and $8.74 \pm 2.83 \mathrm{mg} \mathrm{kg}^{-1}$ dry weight of arsenic. This is clearly indicates that the agricultural soil of the study area has become highly contaminated with arsenic due to the excessive use of arsenic rich groundwater for irrigation.

It can be seen that for all the studied samples the soil arsenic concentration was below the maximum acceptable limit for agricultural soil of $20.0 \mathrm{mg} \mathrm{kg}^{-1}$ as recommended by the European Community (Rahman et al., 2007; O'Neil, 1995 and Smith, 1998), but the arsenic concentration in groundwater was found to be much higher than the recommended World Health Organization permissible limit $0.01 \mathrm{mgl}^{-1}$ for drinking water (Rahman et al., 2007; O'Neil, 1995 and Smith, 1998), and Food and Agriculture Organization permissible limit for irrigation water $\left(0.10 \mathrm{mg} \mathrm{l}^{-1}\right)$ (FAO, 1985).

Long term use of arsenic contaminated groundwater for irrigation may result in the further increase of arsenic concentration in the agricultural soil and eventually hyperaccumulation in crops including rice plants. The accumulation of arsenic ( $\mathrm{mg} \mathrm{kg}^{-1}$ dry weight) of rice grain was found to have the following ranges: $0.12 \pm 0.04$ to $0.58 \pm 0.06$ in boro, $0.16 \pm 0.04$ to $1.06 \pm 0.20$ in T. Aman. Graphical representation of the distribution of arsenic in soil, irrigation water, boro and T. Aman grain of different unions in Chandina is shown in Figures $1-4$.

Table 1. Soil characteristics of the arsenic contaminated rice fields of Chandina upazilla of Comilla district (mean \pm SE)

\begin{tabular}{lc}
\hline Soil parameters & Values \\
\hline Clay (\%) & 5.00 \\
Sand (\%) & 17.19 \\
Silt $(\%)$ & 77.86 \\
Texture & Silt loam \\
pH & $6.12 \pm 0.04$ \\
Organic carbon $(\%)$ & $0.98 \pm 0.04$ \\
\hline
\end{tabular}


Table 2. Concentrations of arsenic (ppm) in irrigation water, soil and in grain of rice plant cultivated in the Chandina upazilla of Comilla district (mean \pm SE, SD and Range)

\begin{tabular}{|c|c|c|c|c|c|c|c|c|c|c|c|c|}
\hline \multirow[t]{2}{*}{ Union } & \multicolumn{3}{|c|}{ Irrigation water } & \multicolumn{3}{|c|}{ Soil } & \multicolumn{3}{|c|}{ Rice grain (Boro) } & \multicolumn{3}{|c|}{ Rice grain (T.Aman) } \\
\hline & mean $\pm \mathrm{SE}$ & Range & SD & mean $\pm \mathrm{SE}$ & Range & SD & mean \pm SE & Range & SD & mean $\pm \mathrm{SE}$ & Range & SD \\
\hline Mahicha $(n=4)$ & $0.31 \pm 0.09$ & $0.15-0.49$ & 0.18 & $8.09 \pm 2.02$ & $4.71-14.98$ & 4.04 & $0.26 \pm 0.04$ & $0.19-0.35$ & 0.08 & $0.78 \pm 0.25$ & $0.12-1.26$ & 0.50 \\
\hline Gollai $(n=4)$ & $0.12 \pm 0.08$ & $0.01-0.36$ & 0.16 & $3.21 \pm 0.80$ & $1.54-5.36$ & 1.60 & $0.12 \pm 0.04$ & $0.03-0.25$ & 0.08 & $1.06 \pm 0.20$ & $0.59-1.51$ & 0.40 \\
\hline $\begin{array}{l}\text { Dollai Nababpur } \\
(\mathrm{n}=5)\end{array}$ & $0.29 \pm 0.07$ & $0.13-0.47$ & 0.16 & $6.00 \pm 0.92$ & $2.83-8.30$ & 2.06 & $0.24 \pm 0.06$ & $0.12-0.45$ & 0.13 & $0.52 \pm 0.09$ & $0.16-0.68$ & 0.20 \\
\hline Madhaia $(\mathrm{n}=5)$ & $0.18 \pm 0.06$ & $0.03-0.37$ & 0.13 & $4.98 \pm 0.60$ & $3.49-6.59$ & 1.34 & $0.23 \pm 0.07$ & $0.13-0.37$ & 0.16 & $0.72 \pm 0.09$ & $0.54-1.07$ & 0.20 \\
\hline Joag $(n=5)$ & $0.67 \pm 0.07$ & $0.52-0.91$ & 0.16 & $8.74 \pm 2.53$ & $3.96-16.73$ & 5.67 & $0.58 \pm 0.05$ & $0.46-0.73$ & 0.11 & $0.67 \pm 0.07$ & $0.52-0.91$ & 0.16 \\
\hline Borokarai $(n=5)$ & $0.45 \pm 0.14$ & $0.12-0.94$ & 0.31 & $8.18 \pm 2.20$ & $3.25-14.58$ & 4.93 & $0.38 \pm 0.11$ & $0.14-0.81$ & 0.25 & $0.45 \pm 0.14$ & $0.12-0.94$ & 0.31 \\
\hline Maijkhar $(n=5)$ & $0.15 \pm 0.06$ & $0.03-0.34$ & 0.13 & $3.84 \pm 1.90$ & $0.33-9.77$ & 4.26 & $0.23 \pm 0.05$ & $0.05-0.37$ & 0.11 & $0.16 \pm 0.04$ & $0.05-0.31$ & 0.09 \\
\hline Barera $(n=5)$ & $0.49 \pm 0.12$ & $0.19-0.83$ & 0.27 & $8.55 \pm 1.65$ & $4.23-13.64$ & 3.70 & $0.42 \pm 0.12$ & $0.10-0.73$ & 0.27 & $0.52 \pm 0.06$ & $0.37-0.69$ & 0.13 \\
\hline
\end{tabular}


Figure 1 shows that the highest $(16.73 \mathrm{ppm})$ and lowest $(0.33 \mathrm{ppm})$ concentration of arsenic were found in soil of Joag and Maijkhar union respectively. The Figure 2 shows that the highest (0.94 ppm) and lowest $(0.01 \mathrm{ppm})$ concentration of arsenic were found in irrigation water of Borokorai and Gollai union, respectively. Figure
3 shows that the highest $(0.81 \mathrm{ppm})$ and lowest (0.03 ppm) concentration of arsenic were found in irrigation water of Borokorai and Gollai union, respectively. Figure 4 shows that the highest $(1.51 \mathrm{ppm})$ and lowest $(0.05 \mathrm{ppm})$ concentration of arsenic were found in T. Aman grain of Gollai and Maijkhar union, respectively.

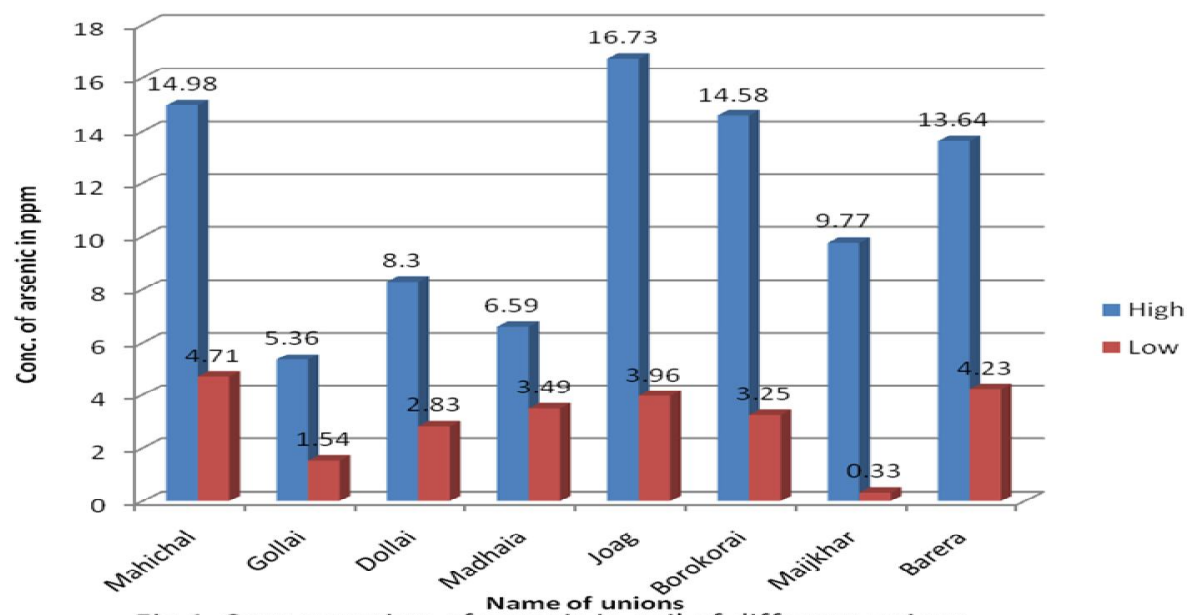

Fig.1. Concentration of arsenic in soil of different unions chandina

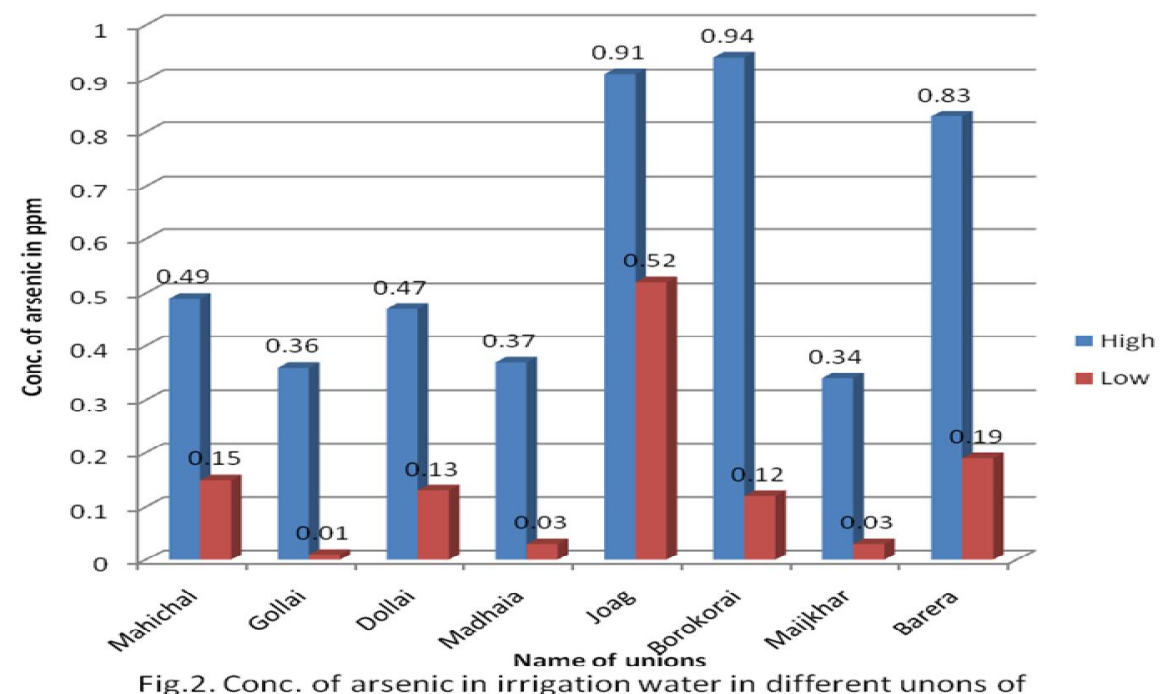

Fig.2. Conc. of arsenic in irrigation water in different unons of Chandina 

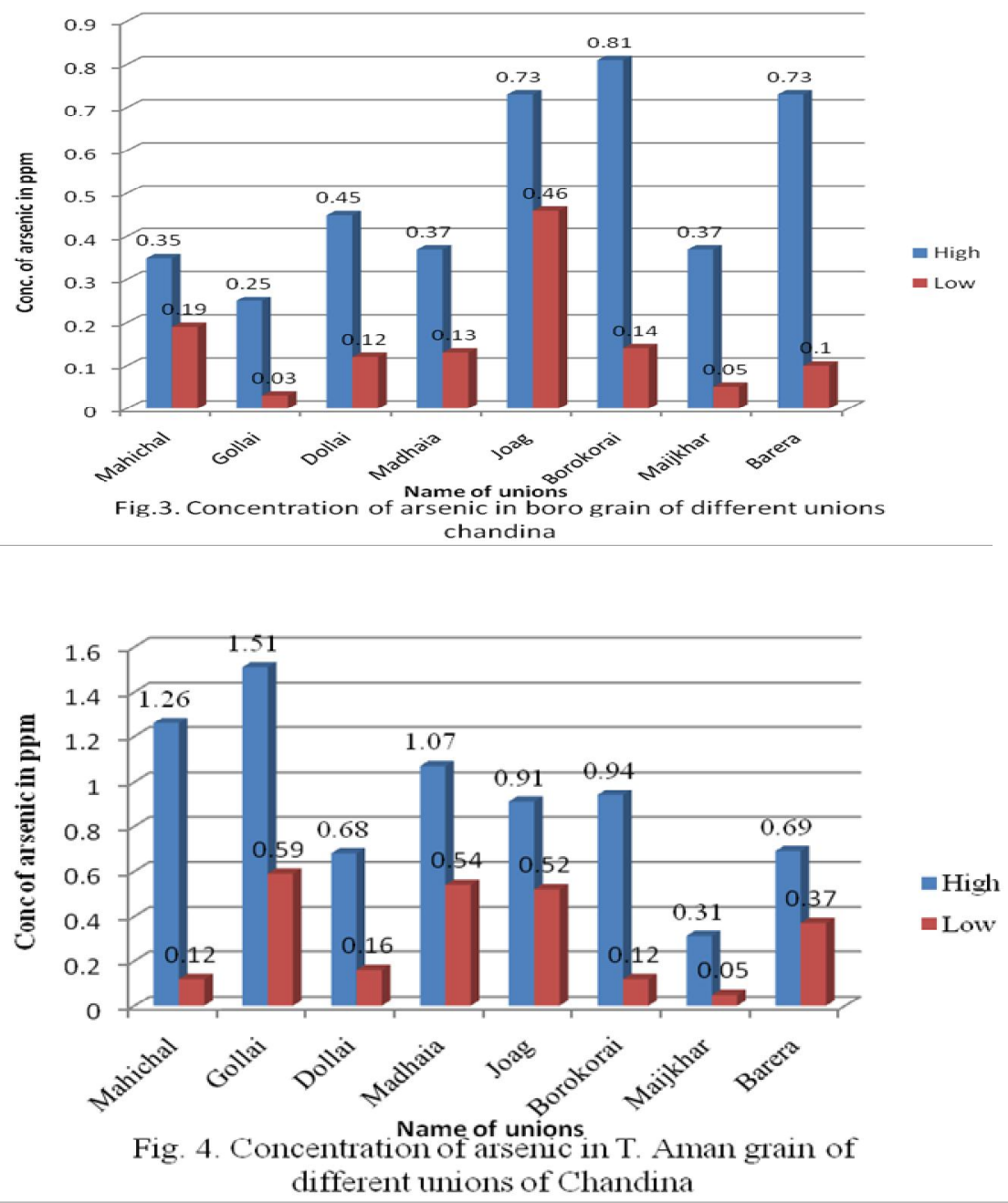

The results reveal that arsenic supplied with irrigation water accumulates mostly much less in rice grains of boro and $\mathrm{T}$. Aman except rice grain of T. Aman in Gollai union (1.06 $\left.\pm 0.20 \mathrm{mg} \mathrm{kg}^{-1}\right)$ in Table: 2. The concentration of arsenic in the grain of boro and T. Aman all the studied rice samples were found to be between $0.12 \pm 0.04$ to $0.58 \pm 0.06$ and $0.16 \pm 0.04$ to $1.06 \pm 0.20$ $\mathrm{mg} \mathrm{kg}{ }^{-1}$ dry weight of arsenic, which did not exceed the permissible limit in rice $\left(1.0 \mathrm{mg} \mathrm{kg}^{-1}\right)$ according to WHO recommendation (Rahman et al., 2007; Abedin et al., 2002 and Das et al., 2004). The remarkable shielding of rice grains from the contaminated irrigation water and from the soil arsenic is consistent with several previous studies (Rahman et al., 2007; Abedin et al., 2002 and Liu et al., 2006). The outer fraction of rice (husk) might act as a translocation barrier for which arsenic could not mobilize easily into the rice grains. The children spend a considerable amount of time playing in the fields surrounding their village. Wasserman et al. 
(2004) have shown that the mental development of the children is impaired by the exposure of arsenic to the children is of particular concern.

The correlation coefficients (r) among arsenic concentrations in irrigation water, soil and grain of the rice plant is shown in Table 3. It is interesting to note the fact that the arsenic content of the soil is highly significantly correlated with the arsenic content of irrigation water $(r=0.894)$. This clearly indicates that the usage of arsenic rich irrigation water in the study area have contaminated the agricultural soil with arsenic. Significant correlation is obtained between arsenic contaminated irrigation water and rice grain of boro $(\mathrm{r}=0.971)$ as because cultivation of boro rice mostly depend irrigation water. Non- significant but negative correlation of the arsenic content in boro grain with the arsenic contents in T. Aman grain $(r=-0.244)$. Non-significant and negative correlation was found between irrigation water and rice grain of T.Aman $(r=-0.121)$ as because cultivation of T.Aman mostly rainfed condition. There is a negaitive but insignificant correlation is obtained between soil and both in the grain. Thus, from the results it can be concluded that the arsenic contaminated irrigation water and the agricultural field soil are highly responsible for the transfer and uptake of arsenic in rice plant.

\section{Conclusions}

The level of arsenic in irrigation water in the study area is very much above the WHO permissible limit of $0.01 \mathrm{mg}^{-1}$ for drinking water and FAO permissible limit of $0.10 \mathrm{mg} \mathrm{l}^{-1}$ for irrigation water. Soil gets contaminated with arsenic due to the irrigation with the arsenic contaminated water. Although it is got clear that the arsenic is transferred from irrigation water and paddy soil to grain of the rice plant with different pattern of distribution, the results suggest that irrigation with groundwater enriched in arsenic affects the rice grain quite limitedly. Except one, all of the studied samples the concentration of arsenic in rice grain exceeds the permissible limit of $1.0 \mathrm{mg} \mathrm{kg}$ dry weight (WHO recommendation). There may be a number of options for reducing inflow of arsenic in rice fields. The concentration of As in STW water decreases with increasing well depth therefore, pumping irrigation water from the greater depth might lead to decrease in the arsenic load to the rice fields. Another option is the economic use of irrigation water by reducing the depth of ponded water and by alternate wetting/ drying practice for Boro rice cultivation.

\section{Acknowledgements}

The authors are thankful to the Bangladesh Agriculture Research Council (BARC) for providing fund to carry out the investigation and to the District Office of Soil Resource Development Institute (SRDI), Comilla and Upazilla Agriculture Office, Chandina, Comilla for collecting samples. We are thankful to the Central Laboratory of Soil Resource Development Institute (SRDI) for providing analytical facilities.

Table 3. Correlation coefficients ( $\mathrm{r}$ ) among arsenic concentrations in irrigation water, soil and in grain of the rice plant cultivated in the Chandina upazilla of Comilla district $(n=38)$.

\begin{tabular}{lllll}
\hline & Irrigation water & Soil & Grain (Boro) & Grain (T.Aman) \\
\hline Irrigation water & 1.000 & & & \\
Soil & $0.894^{* *}$ & 1.000 & & \\
Grain (Boro) & $0.971^{* *}$ & $0.823^{* *}$ & 1.000 & \\
Grain (T. Aman) & -0.121 & -0.110 & -0.244 & 1.000 \\
\hline
\end{tabular}

** Significant at 0.01 level (1-Tailed) 


\section{References}

Abedin, M. J., M. S. Cresser, A. A. Meharg, J. Feldmann and J. Cotter-Howells, 2002. Arsenic accumulation and metabolism in rice (Oryza sativa L.). Environmental Science and Technology, 36(5): 962-8.

Alam M. G. M., Allison, G., Stagnitti, F., Takane, A. and Westbrooke, M. 2002. Arsenic Contamination in Bangladesh groundwater: a great environmental and social disaster. International Journal of Environmental Health Research. 12(3):235-253.

Ali, M. M., Ishiga, H. and Wakatsuki, T. 2003. Influence of soil type and properties on distribution and changes in arsenic contents of different paddy soils in Bangladesh. Soil Science and Plant Nutrition. 49(1):111-123.

Das, H. K., A. K. Mitra, P. K. Sengupta, A. Hossain, F. Islam and G. H. Rabbani, 2004. Arsenic concentrations in rice, vegetables and fish in Bangladesh: a preliminary study. Environment International, 30(3): 383-387.

Delowar, H. K. M., I. Yoshida, M. Harada, A. A. Sarkar, M. N. H. Miah, A. H. M. Razzaque, M. I. Uddin, K. Adhana and M. F. Perveen, 2005.Growth and uptake of arsenic by rice irrigated with Ascontaminated water. Journal of Food, Agriculture and Environment, 3(2): 287291.

Duxbury, J. M., Mayer, A. B., Lauren, J. G. And Hassan, N. 2003. Food chain aspects of arsenic contamination in Bangladesh: Effects on quality and productivity of rice. Journal of Environmental Science and Health, 38(1):61-69.

FAO, 1985. Water quality guidelines for maximum crop production. Food and Agricultural Organization /UN. www.fao.org/ docrep/T0551E.2006/9/13.
Islam, M. R., Jahiruddin, M. and Islam, S. 2004. Assessment of arsenic in the water-soilplant systems in Gangetic floodplains of Bangladesh. Asian Journal of Plant Science. 3(4): 489- 493.

Jahiruddin, M., Harada, H., Hatanaka, T. and Islam, M. R. 2000. Trace element status in agricultural soils and factors affecting their concentration. Soil Science and Plant Nutrition. 46(4): 963-968.

Liu, W. J., Y. G. Zhu, Y. Hu, P. N. Williams, A. G. Gault, A. A. Meharg, J. M. Charnock and F.A. Smith, 2006. Arsenic Sequestration in Iron Plaque, Its Accumulation and Speciation in Mature Rice Plants (Oryza sativa L.). Environmental Science and Technology, 40: 5730-5736.

Marin, A. R., P. H. Masscheleyn and W. H. Patrick, 1992. The influence of chemical form and concentration of arsenic on rice growth and tissue arsenic concentration. Plant and Soil, 139: 175-183.

Meharg, A. A., and Rahman, M. M. 2003. Arsenic contamination of Bangladesh paddy field soils: Implications for Rice Contribution to Arsenic consumption. Environmental Science and Technology, 37(2):229-234

Nickson, R., McArthur, J. M., Burgess, W., Ahmed, K. M., Ravenscroft, P., and Rahman, M. 1998.Arsenic poisoning of Bangladesh groundwater. Nature, 396, 338 .

O'Neil, P., 1995. Heavy metals in soils. In Arsenic, Ed., Alloway, B. J., Blackie Academic and Professional, London, 105$121 \mathrm{pp}$.

Rahman, M. A., H. Hasegawa, M. M. Rahman, M. A. M. Miah and A. Tasmin, 2008. Arsenic accumulation in rice (Oryza sativa L.): Human exposure through food chain. Ecotoxicology and Environmental Safety, 69: 317-324. 
Rahman, M. A., H. Hasegawa, M. M. Rahman, M. A. Rahman and M. A. M. Miah, 2007. Accumulation of arsenic in tissues of rice plant (Oryza sativa L.) and its distribution in fractions of rice grain. Chemosphere, 69: 942-948.

Smith, A. H., E. O. Lingas and M. Rahman, 2000. Contamination of drinking water by arsenic in Bangladesh: A public health emergency. Bulletin. WHO, 78(9): 10931103.

Wasserman, G. A., X. Liu, F. Parvez, H. Ahsan, P. Factor-Litvak and A. Van Geen, 2004. Water arsenic exposure and children's intellectual function in Araihazar,
Bangladesh. Environmental Health Perspective, 112: 1329-1333.

Welsch, F.P., J.G. Crock and R. Sanzolone, 1990. Trace elements determination of arsenic and selenium using continuous flow hydride generation atomic absorption spectrophotometry (HG-AAS). In Quality Assurance Manual for the Branch of Geochemistry, Ed., Arbogast, B. F., 38-45 pp.

WHO, 1992. Guideline for Drinking Water Quality, Recommendation, Vol 1, 2nd edition. Geneva: World Health Organization, $41 \mathrm{pp}$. 